\title{
Substitution rate and milk yield response to corn silage supplementation of late-lactation dairy cows grazing low-mass pastures at 2 daily allowances in autumn
}

\author{
L. A. Pérez-Prieto, ${ }^{\star} \dagger$ J. L. Peyraud ${ }^{*} \dagger$ and R. Delagarde ${ }^{*} \dagger^{1}$ \\ *INRA, UMR1080, Production du Lait, F-35590 Saint-Gilles, France \\ †Agrocampus Ouest, UMR1080, Production du Lait, F-35000 Rennes, France
}

\begin{abstract}
Feed costs in dairy production systems may be decreased by extending the grazing season to periods such as autumn when grazing low-mass pastures is highly probable. The aim of this autumn study was to determine the effect of corn silage supplementation [0 vs. $8 \mathrm{~kg}$ of dry matter (DM) of a mixture $7: 1$ of corn silage and soybean meal] on pasture intake (PI), milk production, and grazing behavior of dairy cows grazing low-mass ryegrass pastures at 2 daily pasture allowances $(\mathrm{PA}$; low $\mathrm{PA}=18 \mathrm{vs}$. high $\mathrm{PA}=30 \mathrm{~kg}$ of $\mathrm{DM} /$ cow above $2.5 \mathrm{~cm}$ ). Twelve multiparous Holstein cows were used in a $4 \times 4$ Latin square design with 14-d periods. Pre-grazing pasture mass and pre-grazing plate meter pasture height averaged $1.8 \mathrm{t}$ of $\mathrm{DM} / \mathrm{ha}$ (above $2.5 \mathrm{~cm}$ ) and $6.3 \mathrm{~cm}$, respectively. The quality of the offered pasture (above $2.5 \mathrm{~cm}$ ) was low because of dry conditions before and during the experiment (crude protein $=11.5 \%$ of DM; net energy for lactation $=5.15$ $\mathrm{MJ} / \mathrm{kg}$ of DM; organic matter digestibility $=61.9 \%$ ). The interaction between PA and supplementation level was significant for PI but not for milk production. Supplementation decreased PI from 11.6 to $7.6 \mathrm{~kg}$ of $\mathrm{DM} / \mathrm{d}$ at low $\mathrm{PA}$ and from 13.1 to $7.3 \mathrm{~kg}$ of $\mathrm{DM} / \mathrm{d}$ at high PA. The substitution rate was, therefore, lower at low than at high PA (0.51 vs. 0.75). Pasture intake increased with increasing PA in unsupplemented treatments, and was not affected by PA in supplemented treatments. Milk production averaged $13.5 \mathrm{~kg} / \mathrm{d}$ and was greater at high than at low PA $(+1.4 \mathrm{~kg} / \mathrm{d})$ and in supplemented than unsupplemented treatments $(+5.2$ $\mathrm{kg} / \mathrm{d}$ ). Milk fat concentration averaged $4.39 \%$ and was similar between treatments. Milk protein concentration increased from 3.37 to $3.51 \%$ from unsupplemented to supplemented treatments, and did not vary according to PA. Grazing behavior parameters were only affected by supplementation. On average, daily grazing time
\end{abstract}

Received January 27, 2011.

Accepted April 3, 2011.

${ }^{1}$ Corresponding author: remy.delagarde@rennes.inra.fr decreased (539 vs. $436 \mathrm{~min}$ ) and daily ruminating time increased (388 vs. $486 \mathrm{~min}$ ) from 0 to $8 \mathrm{~kg}$ of supplement DM. The PI rate was $6 \mathrm{~g}$ of $\mathrm{DM} / \mathrm{min}$ lower in supplemented than in unsupplemented treatments (17 vs. $23 \mathrm{~g}$ of $\mathrm{DM} / \mathrm{min}$ ). The high milk yield response to supplementation may be related to a cumulative effect of the low-mass pasture (low PI) and the low quality of the pasture, which strongly limited energy supply in unsupplemented cows.

Key words: dairy cow, low-mass pasture, corn silage, substitution rate

\section{INTRODUCTION}

In dairy production systems, efficiently grazed pasture is recognized as a low-cost source of nutrients (Dillon et al., 2005). Accordingly, rising production costs and falling farm-gate product prices in recent years have underlined the advantage of extending the grazing season and, hence, maximizing the proportion of grazed pasture in the annual diet of dairy cows. In autumn, weather conditions usually decrease pasture growth, increasing the probability of grazing short swards (i.e., low-mass pastures) when extending the grazing season. Pasture availability is usually low at the farm level and forage supplementation such as corn silage is a good alternative for increasing the nutrient supply of dairy cows.

Previous research has demonstrated that offering corn silage to grazing dairy cows decreases pasture intake (PI) as a result of the substitution of pasture with supplement (Morrison and Patterson, 2007; Burke et al., 2008). The substitution rate (SR; i.e., the decrease of pasture DMI per kilogram of supplement DM) is a major factor contributing to the milk yield response (i.e., the extra milk produced per kilogram of supplement DM). According to the review of McGilloway and Mayne (1996), the greatest benefit of supplementing with forage (i.e., low SR and high milk yield response) is obtained when pasture availability is limited. This has been well established for dairy cows strip-grazing medium- to high-mass pastures. At low pasture allow- 
ance (PA), the SR is low (0.0 to 0.4 ) and high milk yield responses are recorded (i.e., 0.4 to $1.0 \mathrm{~kg} / \mathrm{kg}$ of corn silage DM; Moran and Croke, 1993; Woodward et al., 2002; Burke et al., 2008). Conversely, when pasture availability is not limiting (i.e., at high PA), the SR is high (0.5 to 1.0) and the milk yield response is quite low (i.e., $<0.4 \mathrm{~kg} / \mathrm{kg}$ of corn silage DM; Moran et al., 1986; Graf et al., 2005; Morrison and Patterson, 2007). Little information is available about the SR of forage-supplemented dairy cows on low-mass pastures. Stockdale and Dellow (1995), Stockdale (1996), and Stockdale (1997) worked with corn silage-supplemented cows grazing low-mass pastures. However, pastures were pure white clover or pure paspalum with particular structure and quality compared with the most widely grazed pastures in temperate zones.

Low-mass pastures are well known to decrease PI and milk production under continuously stocked management (Rook et al., 1994; Gibb et al., 1997). On lowmass pastures, cows are forced to graze very low strata, PI rate being strongly decreased because of the reduction of bite mass (Gibb et al., 1997). On the daily scale, cows attempt to maintain PI by increasing grazing time, but in the presence of very short swards, cows are unable to fully compensate for the decrease in intake rate (McGilloway and Mayne, 1996). Consequently, under strip-grazing management, grazing low-mass pastures may also affect PI and milk production responses to PA and corn silage supplementation.

The aim of the present study was, therefore, to determine the effect of PA and corn silage supplementation on PI, SR, milk production, and grazing behavior of dairy cows strip-grazing low-mass pastures in autumn. This will allow a better understanding of the PI regulation of corn silage-supplemented cows grazing low-mass pastures when extending the grazing season.

\section{MATERIALS AND METHODS}

\section{Treatments and Experimental Design}

Two PA (low PA $=18$ vs. high PA $=30 \mathrm{~kg}$ of $\mathrm{DM} / \mathrm{d}$ above $2.5 \mathrm{~cm}$ ) and 2 supplementation levels (0 vs. $8 \mathrm{~kg}$ of $\mathrm{DM} / \mathrm{d}$ ) were compared in a $2 \times 2$ factorial arrangement. The supplement, balanced for net energy and protein as recommended by INRA (2007), was a mixture 7:1 on DM basis of corn silage and soybean meal. The supplement was offered individually after the a.m. milking (between 0800 and $0900 \mathrm{~h}$; Table 1). Treatments were compared in a $4 \times 4$ Latin square design, replicated 3 times, and balanced for carryover effects (Jones and Kenward, 1989). The study was conducted in autumn from September 19 to November 13, 2008, in 4 consecutive 14-d periods. Each period included 8
Table 1. Chemical composition and nutritive value of supplements (corn silage and soybean meal)

\begin{tabular}{|c|c|c|}
\hline \multirow[b]{2}{*}{ Item } & \multicolumn{2}{|c|}{ Supplement } \\
\hline & $\begin{array}{c}\text { Corn } \\
\text { silage }\end{array}$ & $\begin{array}{c}\text { Soybean } \\
\text { meal }\end{array}$ \\
\hline DM, $\%$ & 29.2 & 90.4 \\
\hline \multicolumn{3}{|l|}{ Chemical composition, \% of DM } \\
\hline $\mathrm{OM}$ & 96.1 & 92.8 \\
\hline $\mathrm{CP}$ & 5.9 & 49.8 \\
\hline $\mathrm{NDF}$ & 38.7 & 9.1 \\
\hline $\mathrm{ADF}$ & 23.5 & 5.5 \\
\hline $\mathrm{ADL}^{1}$ & 2.6 & 0.7 \\
\hline Starch & 33.4 & 5.4 \\
\hline \multicolumn{3}{|l|}{ Nutritive value } \\
\hline OM digestibility, ${ }^{2} \%$ & 73.4 & 89.6 \\
\hline $\mathrm{NE}_{\mathrm{L}}, \mathrm{MJ} / \mathrm{kg}$ of $\mathrm{DM}$ & 6.73 & 7.65 \\
\hline $\mathrm{PDIN}^{3}, \mathrm{~g} / \mathrm{kg}$ of DM & 36 & 358 \\
\hline $\mathrm{PDIE},{ }^{4} \mathrm{~g} / \mathrm{kg}$ of $\mathrm{DM}$ & 65 & 241 \\
\hline
\end{tabular}

${ }^{1}$ Acid detergent lignin.

${ }^{2}$ Calculated from pepsin-cellulase digestibility (Aufrère and MichaletDoreau, 1988).

${ }^{3}$ Protein truly digested in the intestine, with nitrogen-limiting microbial synthesis in the rumen (INRA, 2007).

${ }^{4}$ Protein truly digested in the intestine, with energy-limiting microbial synthesis in the rumen (INRA, 2007).

$\mathrm{d}$ of adaptation and $6 \mathrm{~d}$ of animal measurements (from d 9 to 14).

\section{Animals}

Twelve multiparous Holstein-Friesian dairy cows in late lactation were split into 4 groups of 3 individuals. The groups were balanced according to lactation stage $(230 \pm 23$ DIM), milk production at peak (38.9 $\pm 2.7 \mathrm{~kg})$, milk production $(17.9 \pm 2.3 \mathrm{~kg})$, milk fat concentration $(4.02 \pm 0.65 \%)$, milk protein concentration $(3.03 \pm 0.15 \%), \mathrm{BW}(593 \pm 48 \mathrm{~kg})$, and $\mathrm{BCS}$ $(2.2 \pm 0.2$, scale $0-5)$ measured in a pre-experimental period from August 25 to September 14. During this 21-d period, the cows grazed non-experimental pasture day and night and were supplemented daily with $5 \mathrm{~kg}$ of corn silage DM, $3 \mathrm{~kg}$ of grass silage DM, and $2.7 \mathrm{~kg}$ of concentrate DM. From September 15 to September 18 , the supplementation was changed to $4.5 \mathrm{~kg}$ of corn silage DM/d and $0.5 \mathrm{~kg}$ of soybean meal DM/d. Cows were milked twice daily at 0700 and $1700 \mathrm{~h}$.

\section{Grazing Management and Pasture}

The study was conducted at the INRA experimental farm of Méjusseaume $\left(1.71^{\circ} \mathrm{W}, 48.11^{\circ} \mathrm{N}\right.$, Brittany, France) on perennial ryegrass pastures (Lolium perenne L. cultivar 'Ohio') sown 4 yr previously. The pastures were rotationally grazed by a dairy herd during the summer 2008 to keep a low pasture mass in early Au- 
gust (post-grazing plate meter pasture height $=4.0$ $\mathrm{cm})$.

Two paddocks were grazed throughout the experiment. Within each paddock, the 4 treatment groups grazed as separated herds, working in a strip-grazing system. All herds grazed adjacent sub-paddocks, defined using temporary electric fences. The area allocated daily to each treatment was adjusted by means of electric fences from a daily estimate of the pre-grazing pasture mass as described in the Feed and Sward Measurements section. Fresh pasture was allocated to the cows each morning after the a.m. milking and the access time at pasture was from 0900 to $1630 \mathrm{~h}$ and from 1730 to 0645 h (i.e., $\sim 21 \mathrm{~h} / \mathrm{d}$ ). Water was always available and the walking distance from pasture to the milking parlor averaged $370 \mathrm{~m}$ (range: 200 to $550 \mathrm{~m}$ ).

\section{Animal Measurements}

Milk production per cow was recorded at each milking. Milk fat concentration and milk protein concentration were determined on the last $4 \mathrm{~d}$ of each experimental period by near infrared spectrophotometry using a Milkoscan instrument (Foss Electric, Hillerød, Denmark). Body weight was recorded on the last day of each experimental period.

Individual PI was estimated from d 9 to 13 of each period with the $n$-alkane technique (Mayes et al., 1986), using the ratio of pasture $\mathrm{C}_{33}$ (tritriacontane) to dosed $\mathrm{C}_{32}$. Throughout the experiment, all cows were dosed twice daily before milking with a cellulose stopper (Carl Roth, GmbH, Karlsruhe, Germany) containing $460 \pm 20 \mathrm{mg}$ of $\mathrm{C}_{32}$. During the $5 \mathrm{~d}$ of measurements, pasture representative of that grazed (selected pasture) was collected as described below in the Feed and Sward Measurements section. Fecal grab samples were collected from each cow twice daily (after milking) from the p.m. milking on d 9 to the a.m. milking on $\mathrm{d} 14$ and stored at $4^{\circ} \mathrm{C}$. On d 14 , the samples were composited by period and by cow, then freeze-dried for chemical analysis.

Individual balances for $\mathrm{NE}_{\mathrm{L}}$ and protein truly digested in the intestine, with energy-limiting microbial synthesis in the rumen (PDIE) were calculated according to INRA (2007) and expressed as the proportion of theoretical requirements satisfied by supply. Theoretical $\mathrm{NE}_{\mathrm{L}}$ requirements were calculated from the pre-experimental BW and the expected $4 \%$ FCM production during the experiment. The calculation of theoretical PDIE requirements included these 2 factors and the pre-experimental milk protein concentration. The expected $4 \%$ FCM production during the experiment was calculated applying a monthly persistency of $90 \%$ from the pre-experimental $4 \%$ FCM produc- tion. Net energy and PDIE supplies were calculated from intake of pasture, corn silage, and soybean meal and from their concentrations of $\mathrm{NE}_{\mathrm{L}}$ and PDIE, respectively. The digestive interactions between forages and concentrates were considered in these calculations (INRA, 2007).

The daily pattern of grazing and ruminating times was measured automatically by recording jaw movements with a portable device (Brun et al., 1984). The 12 cows were simultaneously equipped from d 10 to 14 to obtain at least 3 complete days of recordings per cow during each period. Each day, during the morning milking, the stored data were downloaded to a computer. Interpretative software was used to classify data into one of 3 categories: grazing, ruminating, or other, to build up a behavior profile over 24-h periods. Grazing time during daylight (min) was defined as the grazing time recorded between sunrise and sunset. The same criterion was applied to calculate ruminating time during daylight (min). A grazing bout was defined as a sequence of at least $7 \mathrm{~min}$, and it was considered that 2 consecutive grazing bouts are separated by at least 7 min of non-grazing activity. A ruminating bout was defined as a sequence of at least $5 \mathrm{~min}$, and it was considered that 2 consecutive ruminating bouts are separated by at least $5 \mathrm{~min}$ of non-ruminating activity (Brun et al., 1984). Mean grazing and ruminating bout duration ( $\mathrm{min} /$ bout) were calculated by dividing the grazing and the ruminating time $(\mathrm{min} / \mathrm{d})$, respectively, by the number of bouts (bouts/d). The first grazing bout was defined as the grazing bout just after a.m. milking when fresh pasture was allocated. The PI rate (g of $\mathrm{DM} / \mathrm{min}$ ) was calculated as the ratio of PI ( $\mathrm{kg}$ of $\mathrm{DM} / \mathrm{d})$ to grazing time $(\mathrm{min} / \mathrm{d})$.

\section{Feed and Sward Measurements}

The amounts of corn silage and soybean meal offered were weighed daily for each cow. Dry matter concentration was determined once daily for corn silage and once weekly for soybean meal. Each morning, the presence of refusals in feeders was verified. If any, they were removed and weighed individually. Weekly samples of corn silage and concentrate were collected and composited before chemical analysis.

Pre-grazing pasture mass above $2.5 \mathrm{~cm}$ was measured 3 times per period (generally d 0,6 , and 11) by cutting 3 quadrats of $0.49 \mathrm{~m}^{2}(0.7 \times 0.7 \mathrm{~m})$ per treatment at random. The pasture was cut using an electric manual shear (Elmar Wolf Ltd., Wissembourg, France) at $2.5 \mathrm{~cm}$ above ground level. To calculate the depth of cutting, 4 measurements of the pasture height were made on each quadrat, before and after cutting, with an electronic plate meter $\left(30 \times 30 \mathrm{~cm}, 4.5 \mathrm{~kg} / \mathrm{m}^{2}\right.$; 
AGRO-Systèmes, La Membrolle, France). Sward bulk density above $2.5 \mathrm{~cm}$ was calculated on each quadrat by dividing pasture mass by cutting depth. The pasture collected on each quadrat was weighed and divided into 2 equal parts. The first subsample was oven dried for 48 $\mathrm{h}$ at $80^{\circ} \mathrm{C}$ for the determination of DM concentration. The second was washed with fresh water, then oven dried $\left(80^{\circ} \mathrm{C}\right.$ for $\left.48 \mathrm{~h}\right)$ and composited by treatment and period before chemical analysis.

Pasture mass was estimated at ground level twice per period, generally on $\mathrm{d} 7$ and 12 . In 2 of the 3 quadrats cut at $2.5 \mathrm{~cm}$, an area of $0.1 \mathrm{~m}^{2}$ was cut to ground level using scissors. The pasture samples were washed with fresh water and then oven dried $\left(80^{\circ} \mathrm{C}\right.$ for $\left.48 \mathrm{~h}\right)$. Subsequently, the dry samples were weighed and composited by treatment and period for chemical analysis.

The chemical composition of selected pasture was determined on each treatment from d 9 to 13. Each day, a 600-g sample of pasture, representative of that grazed, was manually collected, imitating the postgrazing sward height of the previous day. Sampling was performed in each treatment during the morning before grazing. An initial subsample was oven dried for $48 \mathrm{~h}$ at $80^{\circ} \mathrm{C}$, then composited by treatment and period for chemical analysis. A second subsample was stored at $-20^{\circ} \mathrm{C}$. Then, on $\mathrm{d} 13$, it was composited by treatment and period before $n$-alkane analysis. Finally, a third and final subsample was divided in 2 fractions: live or dead material. These items were stored at $-20^{\circ} \mathrm{C}$, then composited by period for $n$-alkane analysis. The live/dead material ratio in the selected pasture was estimated by minimizing the sum of squares of the discrepancy between the measured $n$-alkane $\mathrm{C}_{25}$ to $\mathrm{C}_{35}$ concentrations in the selected pasture and that estimated from the $n$-alkane concentrations of the live and dead material components weighed by their respective proportion on a DM basis.

Pre- and post-grazing sward heights were measured daily in each treatment using a rising plate meter (50 measurements). Each day, this pre-grazing pasture height (minus $2.5 \mathrm{~cm}$ ) was multiplied by sward bulk density above $2.5 \mathrm{~cm}$ to estimate the pre-grazing pasture mass above $2.5 \mathrm{~cm}$ and daily area to be offered according to the treatment.

On d 8 and 13, pre-grazing extended tiller and highest sheath heights were measured with a ruler on 50 tillers per treatment. Post-grazing tiller and sheath extended heights were measured on d 11 and 14 on 50 tillers per treatment.

\section{Chemical Analyses}

The dried pasture, corn silage and soybean meal samples, along with the freeze-dried feces and pasture samples, were milled through a $0.8-\mathrm{mm}$ sieve before chemical analysis. Ash was determined by calcination at $550^{\circ} \mathrm{C}$ for $5 \mathrm{~h}$ (Association Française de Normalisation, 1997) in a muffle furnace. Nitrogen concentration was determined by the Dumas method (Association Française de Normalisation, 1997) on a Leco instrument (Leco Corp., St. Joseph, MI). Pepsin-cellulase digestibility of pasture was determined according to Aufrère and Michalet-Doreau (1988). The concentrations of NDF, ADF, and acid detergent lignin were measured according to Van Soest et al. (1991) on a Fibersac extraction unit (Ankom Technology Corp., Fairport, NY). $N$-alkanes were determined, after freeze-drying, according to Mayes et al. (1986) following direct saponification (Vulich et al., 1991). The net energy value and PDIE of feeds were calculated from their chemical composition according to INRA (2007).

\section{Statistical Analyses}

Animal and pasture data were analyzed as a $4 \times 4$ Latin square design, with a $2 \times 2$ factorial arrangement of the treatments. Data on one cow in period 1 were removed before statistical analysis because of cow health problems unrelated to the experiment. The model for animal variables $(\mathrm{n}=47)$, averaged per cow and period, were analyzed by using the following model (PROC MIXED; SAS Institute, 1999):

$$
\begin{gathered}
\mathrm{Y}_{\mathrm{ijkl}}=\mu+\operatorname{cow}_{\mathrm{i}}+\text { period }_{\mathrm{j}}+\text { allowance }_{\mathrm{k}} \\
+ \text { supplementation }_{\mathrm{l}}+\left[\text { allowance }_{\mathrm{k}}\right. \\
\left.\times \text { supplementation }_{\mathrm{l}}\right]+e_{\mathrm{ijkl}},
\end{gathered}
$$

where $\mathrm{Y}_{\mathrm{ijk}}, \mu, \operatorname{cow}_{\mathrm{i}}$, period ${ }_{\mathrm{j}}$, allowance $\mathrm{al}_{\mathrm{k}}$, supplementation $_{l}$, [allowance $\mathrm{k} \times$ supplementation $\left._{1}\right]$, and $e_{\mathrm{ijkl}}$ represent the analyzed variable, the overall mean, the random effect of the cow, the fixed effect of the period, the fixed effect of PA, the fixed effect of supplementation, the interaction between PA and supplementation, and the residual error term, respectively.

The model for pasture variables, as well as for $4 \%$ FCM production per hectare $(n=16)$, averaged per treatment and period, was analyzed by using the following model (PROC GLM; SAS Institute, 1999):

$$
\begin{aligned}
\mathrm{Y}_{\mathrm{jkl}}= & \mu+\text { period }_{\mathrm{j}}+\text { allowance }_{\mathrm{k}}+\text { supplementation }_{1} \\
& \left.+ \text { allowance }_{\mathrm{k}} \times \text { supplementation }_{\mathrm{l}}\right]+e_{\mathrm{jk} \mathrm{l}} .
\end{aligned}
$$

The least squares means and standard error of the difference (SED) are reported for all data. The ANOVA results detected (1) the mean effect of PA, (2) the mean 
Table 2. Effect of pasture allowance (PA) and corn silage supplementation (S) on pre-grazing pasture characteristics: pasture mass, sward height, chemical composition, and nutritive value of offered pasture

\begin{tabular}{|c|c|c|c|c|c|c|c|c|}
\hline Item & \multicolumn{2}{|c|}{ Low PA } & \multicolumn{2}{|c|}{ High PA } & $\mathrm{SED}^{1}$ & \multicolumn{3}{|c|}{$P$-value } \\
\hline Above $2.5 \mathrm{~cm}$ & 1,710 & 1,760 & 1,920 & 1,750 & 98.0 & 0.181 & 0.375 & 0.141 \\
\hline Above ground level & 3,960 & 3,880 & 4,140 & 3,620 & 228.7 & 0.811 & 0.094 & 0.212 \\
\hline \multicolumn{9}{|c|}{ Pre-grazing sward height, $\mathrm{cm}$} \\
\hline Rising plate meter & 6.2 & 6.3 & 6.6 & 6.2 & 0.21 & 0.193 & 0.413 & 0.127 \\
\hline Extended lamina & 10.3 & 10.6 & 10.8 & 10.4 & 0.40 & 0.625 & 0.820 & 0.309 \\
\hline \multicolumn{9}{|c|}{ Chemical composition, $\%$ of DM } \\
\hline DM, \% & 27.7 & 27.7 & 26.2 & 30.1 & 2.69 & 0.820 & 0.330 & 0.327 \\
\hline $\mathrm{OM}$ & 92.6 & 92.5 & 92.7 & 92.5 & 0.21 & 0.551 & 0.417 & 0.721 \\
\hline $\mathrm{CP}$ & 11.5 & 12.0 & 11.6 & 11.2 & 0.80 & 0.548 & 0.903 & 0.441 \\
\hline NDF & 63.8 & 63.8 & 63.4 & 64.6 & 0.49 & 0.507 & 0.130 & 0.094 \\
\hline $\mathrm{ADF}$ & 28.6 & 28.2 & 28.1 & 28.8 & 0.23 & 0.552 & 0.330 & 0.008 \\
\hline PDIE ${ }^{6} \mathrm{~g} / \mathrm{kg}$ of DM & 78 & 80 & 78 & 76 & 2.1 & 0.408 & 0.918 & 0.210 \\
\hline
\end{tabular}

${ }^{1}$ Standard error of the difference.

${ }^{2}$ Numbers indicate the level of S. $0=0 \mathrm{~kg}$ of supplement DM/d; $8=8 \mathrm{~kg}$ of supplement DM/d.

${ }^{3}$ Acid detergent lignin.

${ }^{4}$ Calculated from pepsin-cellulase digestibility (Aufrère and Michalet-Doreau, 1988).

${ }^{5}$ Protein truly digested in the intestine, with nitrogen-limiting microbial synthesis in the rumen (INRA, 2007).

${ }^{6}$ Protein truly digested in the intestine, with energy-limiting microbial synthesis in the rumen (INRA, 2007).

effect of supplementation, and (3) the mean effect of the interaction between PA and supplementation.

\section{RESULTS}

\section{Weather}

The summer before the experiment was characterized by severe drought during June and July (46 $\mathrm{mm}$ of rainfall, which was approximately $50 \%$ below the 10 yr average). During the experiment (from September 19 to November 13$)$, the total rainfall $(123 \mathrm{~mm})$ and the mean daily temperature $\left(11^{\circ} \mathrm{C}\right)$ were similar to the 10-yr average $\left(162 \mathrm{~mm}\right.$ and $\left.12.5^{\circ} \mathrm{C}\right)$. Periods 1 and 2 were dry, with only $29 \mathrm{~mm}$ of rain and a mean daily temperature of $12.8^{\circ} \mathrm{C}$. The total rainfall increased in periods 3 and 4 (42 and $52 \mathrm{~mm}$, respectively) and the mean daily temperature decreased by $3.6^{\circ} \mathrm{C}$. On average, sunrise was at $0829 \mathrm{~h}$ and sunset at $1916 \mathrm{~h}$, with approximately $11 \mathrm{~h}$ of daylight.

\section{Pre-Grazing Pasture Characteristics}

As expected, pre-grazing pasture characteristics were similar for all treatments (Table 2). Pasture mass averaged $1,780 \mathrm{~kg}$ of DM/ha above $2.5 \mathrm{~cm}$ and $3,900 \mathrm{~kg}$ of
$\mathrm{DM} /$ ha above ground level. The sward bulk density above ground level was $620 \mathrm{~kg}$ of $\mathrm{DM} / \mathrm{ha} / \mathrm{cm}$ because the plate meter pasture height averaged $6.3 \mathrm{~cm}$. The sward bulk density was $850 \mathrm{~kg}$ of DM/ha per $\mathrm{cm}$ below $2.5 \mathrm{~cm}$ and $470 \mathrm{~kg}$ of $\mathrm{DM} /$ ha per $\mathrm{cm}$ above $2.5 \mathrm{~cm}$. Pregrazing extended tiller height averaged $13.4 \mathrm{~cm}$ and extended sheath height $2.9 \mathrm{~cm}$. Accordingly, the extended lamina height represented 0.78 of the extended tiller height $(10.5$ of $13.4 \mathrm{~cm})$.

Pre-grazing chemical composition and nutritive value of the offered pasture did not vary according to either PA or supplementation. The quality of the pasture was low with high concentrations of NDF $(63.9 \%$ of DM) and low levels of $\mathrm{OM}$ digestibility $(61.9 \%), \mathrm{NE}_{\mathrm{L}}(5.15$ $\mathrm{MJ} / \mathrm{kg}$ of DM), CP (11.5\% of DM), PDIE $(78 \mathrm{~g} / \mathrm{kg}$ of $\mathrm{DM})$, and protein truly digested in the intestine, with nitrogen-limiting microbial synthesis in the rumen (PDIN; $75 \mathrm{~g} / \mathrm{kg}$ of DM), indicating a moderate shortage of degradable nitrogen (PDIN < PDIE).

\section{Grazing Management and Post-Grazing Pasture Characteristics}

The effects of PA and supplementation on postgrazing pasture characteristics were additive. Pasture allowance above $2.5 \mathrm{~cm}$ averaged 18 and $31 \mathrm{~kg}$ of DM/d 
Table 3. Effect of pasture allowance (PA) and corn silage supplementation (S) on grazing management and post-grazing pasture characteristics: pasture allowance, offered area, sward height, chemical composition, and nutritive value of selected pasture

\begin{tabular}{|c|c|c|c|c|c|c|c|c|}
\hline \multirow[b]{2}{*}{ Item } & \multicolumn{2}{|c|}{ Low PA } & \multicolumn{2}{|c|}{ High PA } & \multirow[b]{2}{*}{$\mathrm{SED}^{1}$} & \multicolumn{3}{|c|}{$P$-value } \\
\hline & $0^{2}$ & $8^{2}$ & 0 & 8 & & $\mathrm{PA}$ & $\mathrm{S}$ & $\mathrm{PA} \times \mathrm{S}$ \\
\hline Above $2.5 \mathrm{~cm}$ & 18 & 18 & 31 & 31 & 0.3 & 0.001 & 0.218 & 0.100 \\
\hline Above ground level & 42 & 39 & 68 & 64 & 3.5 & 0.001 & 0.229 & 0.812 \\
\hline Offered area, $\mathrm{m}^{2} / \mathrm{cow}$ per day & 105 & 102 & 164 & 177 & 6.4 & 0.001 & 0.380 & 0.109 \\
\hline \multicolumn{9}{|l|}{ Post-grazing sward height, cm } \\
\hline Extended sheath & 2.9 & 3.3 & 3.2 & 3.1 & 0.22 & 0.590 & 0.433 & 0.179 \\
\hline Extended lamina & 2.0 & 3.1 & 3.1 & 4.8 & 0.37 & 0.001 & 0.001 & 0.246 \\
\hline Proportion of lamina-free tillers ${ }^{3}$ & 0.23 & 0.13 & 0.14 & 0.05 & 0.021 & 0.001 & 0.001 & 0.621 \\
\hline \multicolumn{9}{|l|}{ Chemical composition, \% of DM } \\
\hline DM, \% & 22.7 & 20.3 & 20.4 & 18.7 & 1.22 & 0.047 & 0.040 & 0.739 \\
\hline $\mathrm{OM}$ & 87.8 & 88.5 & 88.7 & 90.1 & 0.93 & 0.084 & 0.146 & 0.622 \\
\hline $\mathrm{CP}$ & 13.3 & 14.9 & 14.6 & 16.6 & 0.91 & 0.046 & 0.023 & 0.749 \\
\hline \multicolumn{9}{|l|}{ Nutritive value } \\
\hline $\mathrm{NE}_{\mathrm{L}}, \mathrm{MJ} / \mathrm{kg}$ of $\mathrm{DM}$ & 5.14 & 5.38 & 5.37 & 5.87 & 0.117 & 0.002 & 0.001 & 0.159 \\
\hline $\mathrm{PDIN}^{6}{ }^{6} \mathrm{~g} / \mathrm{kg}$ of DM & 86 & 96 & 95 & 108 & 6.0 & 0.046 & 0.023 & 0.748 \\
\hline $\mathrm{PDIE},{ }^{7} \mathrm{~g} / \mathrm{kg}$ of DM & 80 & 85 & 85 & 92 & 2.1 & 0.004 & 0.003 & 0.384 \\
\hline
\end{tabular}

${ }^{1}$ Standard error of the difference.

${ }^{2}$ Numbers indicate the level of S. $0=0 \mathrm{~kg}$ of supplement DM $/ \mathrm{d} ; 8=8 \mathrm{~kg}$ of supplement DM/d.

${ }^{3}$ Tillers with main lamina totally defoliated.

${ }^{4}$ Acid detergent lignin.

${ }^{5}$ Calculated from pepsin-cellulase digestibility (Aufrère and Michalet-Doreau, 1988).

${ }^{6}$ Protein truly digested in the intestine, with nitrogen-limiting microbial synthesis in the rumen (INRA, 2007).

${ }^{7}$ Protein truly digested in the intestine, with energy-limiting microbial synthesis in the rumen (INRA, 2007).

at low and high PA, respectively (Table 3). This was equivalent to 41 and $66 \mathrm{~kg}$ of $\mathrm{DM} / \mathrm{d}$ above ground level, respectively. The offered area per cow at low PA represented 0.61 of that at high PA (104 vs. $\left.171 \mathrm{~m}^{2} / \mathrm{d}\right)$. Post-grazing plate meter sward height averaged $4.6 \mathrm{~cm}$ and increased by increasing both PA $(P<0.001)$ and supplementation $(P<0.01)$. Similarly, post-grazing extended tiller height increased from low to high PA $(5.6$ vs. $7.2 \mathrm{~cm} ; P<0.001)$ and from 0 to $8 \mathrm{~kg}$ of supplement DM (5.6 vs. $7.2 \mathrm{~cm} ; P<0.001$ ). Post-grazing extended sheath height did not vary between treatments and averaged $3.1 \mathrm{~cm}$. Consequently, the extended lamina height was longer at high than at low PA (4.0 vs. $2.6 \mathrm{~cm}$; $P$ $<0.001)$ and in supplemented than in unsupplemented treatments ( 4.0 vs. $2.6 \mathrm{~cm} ; P<0.001)$. The proportion of lamina-free tillers averaged 0.14 and decreased with increasing both PA and supplementation $(P<0.001)$.

The estimated proportion of dead material in the selected pasture averaged 0.34 . The chemical composition of the selected pasture was similar between treatments, with the exception of CP concentration, which increased from low to high PA (14.1 vs. $15.6 \%$ of DM; $P<0.05)$ and from 0 to $8 \mathrm{~kg}$ of supplement DM (14.0 vs. $15.7 \%$ of DM; $P<0.05)$. The nutritive value of the selected pasture was improved with increasing both PA and supplementation. The quality of the selected pasture remained low, but was nevertheless greater than that of the offered pasture. The difference between the quality of offered and selected pasture was maximal for supplemented cows at high PA.

\section{DMI, Substitution Rate, and Energy Balance}

Supplement DMI averaged $7.7 \mathrm{~kg} / \mathrm{d}$, irrespective of PA, including $6.7 \mathrm{~kg}$ of corn silage and $1.0 \mathrm{~kg}$ of soybean meal. The total DMI averaged $13.8 \mathrm{~kg} / \mathrm{d}$ and increased, when supplement was given, by 3.8 and 1.9 $\mathrm{kg} / \mathrm{d}$ at low and high PA, respectively (interaction of PA $\times$ supplementation; $P<0.05)$. The PI averaged $9.9 \mathrm{~kg}$ of $\mathrm{DM} / \mathrm{d}$ and was lower in supplemented than in unsupplemented treatments (7.5 vs. $12.4 \mathrm{~kg}$ of DM/d; $P<0.001)$. A significant interaction between PA and supplementation was found for PI $(P<0.05$; Table 4$)$. Accordingly, the decrease in PI with increasing supplementation was lower at low than at high PA ( -4.0 vs. $-5.8 \mathrm{~kg}$ of $\mathrm{DM} / \mathrm{d})$. The $\mathrm{SR}$ was, therefore, lower at low 
Table 4. Effect of pasture allowance (PA) and corn silage supplementation (S) on DMI, energy balance, protein balance, milk production, milk composition, BW, pasture harvested, and 4\% FCM production per hectare of dairy cows strip-grazing low-mass pastures in autumn

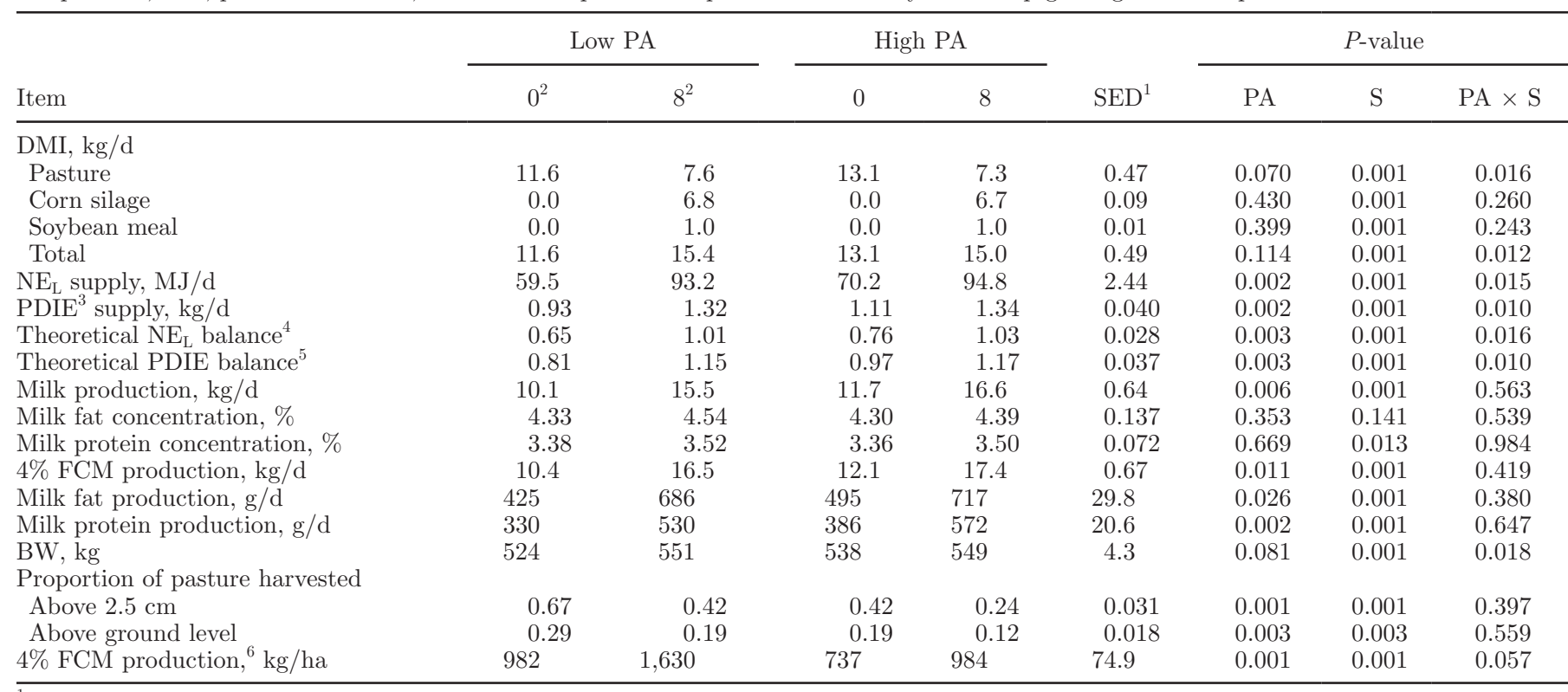

${ }^{1}$ Standard error of the difference.

${ }^{2}$ Numbers indicate the level of S. $0=0 \mathrm{~kg}$ of supplement DM/d; $8=8 \mathrm{~kg}$ of supplement $\mathrm{DM} / \mathrm{d}$.

${ }^{3}$ Protein truly digested in the intestine, with energy-limiting microbial synthesis in the rumen (INRA, 2007).

${ }^{4}$ Proportion of theoretical $\mathrm{NE}_{\mathrm{L}}$ requirements satisfied by $\mathrm{NE}_{\mathrm{L}}$ supply.

${ }^{5}$ Proportion of theoretical PDIE requirements satisfied by PDIE supply.

${ }^{6} \mathrm{In}$ one grazing rotation.

than at high PA and averaged 0.51 and 0.75 , respectively. The pasture DMI increased by $0.06 \mathrm{~kg} / \mathrm{kg}$ of PA above ground level $(0.11 \mathrm{~kg} / \mathrm{kg}$ of PA above $2.5 \mathrm{~cm})$ in unsupplemented treatments and was not affected by PA in supplemented treatments.

The net energy supply averaged $79.4 \mathrm{MJ} / \mathrm{d}$ and was increased by increasing both supplementation and PA $(P<0.01)$. The increase with supplementation, however, was greater at low than at high $\mathrm{PA}(+33.7$ vs. $+24.6 \mathrm{MJ} / \mathrm{d}$; interaction PA $\times$ supplementation; $P<$ 0.05). The same interaction was found for PDIE supply, which also increased more with supplementation at low than at high PA (+0.39 vs. $+0.23 \mathrm{~g} / \mathrm{kg}$ of DM; interaction PA $\times$ supplementation; $P<0.05$ ). The theoretical $\mathrm{NE}_{\mathrm{L}}$ and PDIE balances were greater than 1.0 only in supplemented treatments.

\section{Milk Production, Milk Composition, and BW}

Milk production averaged $13.5 \mathrm{~kg} / \mathrm{d}$ and increased from $10.9 \mathrm{~kg} / \mathrm{d}$ in unsupplemented treatments to 16.1 $\mathrm{kg} / \mathrm{d}$ in supplemented treatments $(P<0.001 ; 0.67 \mathrm{~kg}$ of milk $/ \mathrm{kg}$ of supplement DM). Milk production increased from $12.8 \mathrm{~kg} / \mathrm{d}$ at low PA to $14.2 \mathrm{~kg} / \mathrm{d}$ at high PA $(P<$ $0.01 ; 0.06 \mathrm{~kg} / \mathrm{kg}$ of PA above ground level or $0.11 \mathrm{~kg} /$ $\mathrm{kg}$ of PA above $2.5 \mathrm{~cm}$ ). Milk fat concentration aver- aged $4.39 \%$ and did not vary between treatments. Milk protein concentration increased from 3.37 to $3.51 \%$ from unsupplemented to supplemented treatments $(P$ $<0.05)$, and did not vary according to PA.

Production of $4 \%$ FCM averaged $14.1 \mathrm{~kg} / \mathrm{d}$ and was greater in supplemented than in unsupplemented treatments $(+5.7 \mathrm{~kg} / \mathrm{d} ; P<0.001)$ and at high than at low PA $(+1.3 \mathrm{~kg} / \mathrm{d} ; P<0.05)$. Similarly, milk fat production (average $=581 \mathrm{~g} / \mathrm{d}$ ) and milk protein production (average $=455 \mathrm{~g} / \mathrm{d}$ ) increased from 0 to $8 \mathrm{~kg}$ of supplement DM $(P<0.001)$ and from low to high PA $(P<0.05)$. Supplemented cows were heavier than unsupplemented cows (550 vs. $531 \mathrm{~kg} ; P<0.001$ ), the increase of BW with supplementation being greater at low than at high PA $(+27$ vs. $+11 \mathrm{~kg}$; interaction $\mathrm{PA} \times$ supplementation; $P<0.05)$.

\section{Grazing Behavior}

Grazing behavior parameters were only affected by supplementation (Table 5). On average, unsupplemented cows grazed $103 \mathrm{~min} / \mathrm{d}$ longer than supplemented cows $(P<0.001 ;-13 \mathrm{~min} / \mathrm{kg}$ of supplement DM). Proportionately, 0.79 of grazing time occurred during the $11 \mathrm{~h}$ of daylight $(387 \mathrm{~min})$. The first grazing bout duration for supplemented treatments was more than twice 
Table 5. Effect of pasture allowance (PA) and corn silage supplementation (S) on grazing and ruminating behavior of dairy cows strip-grazing low-mass pastures in autumn

\begin{tabular}{|c|c|c|c|c|c|c|c|c|}
\hline \multirow[b]{2}{*}{ Item } & \multicolumn{2}{|c|}{ Low PA } & \multicolumn{2}{|c|}{ High PA } & \multirow[b]{2}{*}{$\mathrm{SED}^{1}$} & \multicolumn{3}{|c|}{$P$-value } \\
\hline & $0^{2}$ & $8^{2}$ & 0 & 8 & & PA & $\mathrm{S}$ & $\mathrm{PA} \times \mathrm{S}$ \\
\hline Grazing time during daylight, ${ }^{3} \min$ & 421 & 356 & 425 & 344 & 11.4 & 0.668 & 0.001 & 0.331 \\
\hline Grazing time during night, ${ }^{4}$ min & 111 & 84 & 123 & 87 & 11.0 & 0.342 & 0.001 & 0.563 \\
\hline First grazing bout duration, ${ }^{5}$ min & 256 & 132 & 264 & 107 & 12.8 & 0.379 & 0.001 & 0.085 \\
\hline Number of grazing bouts & 5.3 & 6.1 & 5.0 & 5.8 & 0.28 & 0.190 & 0.001 & 0.958 \\
\hline Total ruminating time, $\min / \mathrm{d}$ & 382 & 483 & 393 & 488 & 18.6 & 0.557 & 0.001 & 0.826 \\
\hline Ruminating time during daylight, ${ }^{3}$ min & 67 & 144 & 73 & 144 & 9.9 & 0.674 & 0.001 & 0.712 \\
\hline Ruminating time during night, ${ }^{4}$ min & 313 & 339 & 320 & 344 & 12.2 & 0.498 & 0.001 & 0.871 \\
\hline Number of ruminating bouts & 10.4 & 11.4 & 9.8 & 11.4 & 0.35 & 0.308 & 0.001 & 0.272 \\
\hline Mean ruminating bout duration, min & 38 & 44 & 41 & 44 & 1.6 & 0.132 & 0.001 & 0.186 \\
\hline
\end{tabular}

\footnotetext{
${ }^{1}$ Standard error of the difference.

${ }^{2}$ Numbers indicate the level of S. $0=0 \mathrm{~kg}$ of supplement DM $/ \mathrm{d} ; 8=8 \mathrm{~kg}$ of supplement $\mathrm{DM} / \mathrm{d}$.

${ }^{3}$ Average duration of daylight $=11 \mathrm{~h}$.

${ }^{4}$ Average duration of night $=13 \mathrm{~h}$.

${ }^{5}$ After a.m. milking, when fresh pasture was allocated.
}

shorter than for supplemented treatments (120 vs. 260 $\min ; P<0.001)$. This decrease, however, tended to be lower at low than at high PA ( -124 vs. $-157 \mathrm{~min} ; P=$ 0.09). Supplemented cows had more daily grazing bouts (6.0 vs. $5.2 ; P<0.001)$ than unsupplemented cows, though these were shorter in time (76 vs. $110 \mathrm{~min}$; $P$ $<0.001)$. Moreover, grazing bout duration tended to increase between low and high PA ( 89 vs. $97 \mathrm{~min} ; P$ $=0.08)$. The PI rate was $35 \%$ lower in supplemented than in unsupplemented treatments (17.1 vs. $23.0 \mathrm{~g}$ of $\mathrm{DM} / \mathrm{min} ; P<0.001)$. Daily ruminating time averaged $437 \mathrm{~min}$ and was $98 \mathrm{~min}$ longer in supplemented than unsupplemented treatments $(P<0.001 ; 13 \mathrm{~min} / \mathrm{kg}$ of supplement DM). The proportion of ruminating time during night time was 0.75 (329 min). Ruminating bouts were more abundant $(11.4$ vs. $10.1 ; P<0.001)$ and longer (44 vs. $40 \mathrm{~min} ; P<0.001$ ) in supplemented than in unsupplemented treatments.

The daily pattern of grazing activity was affected mainly by supplementation (Figure 1). In unsupplemented treatments, the cows grazed intensively (i.e., $>45 \mathrm{~min} / \mathrm{h}$ ) during $4 \mathrm{~h}$ after the a.m. milking and during $2 \mathrm{~h}$ after the p.m. milking. The main grazing bout after the a.m. milking was followed by 15 to $35 \mathrm{~min}$ grazing/h until the p.m. milking. The grazing activity was decreased to approximately $20 \mathrm{~min} / \mathrm{h}$ at $2000 \mathrm{~h}$ and varied between 5 and $15 \mathrm{~min} / \mathrm{h}$ from 2100 to $0300 \mathrm{~h}$. Subsequently, cows grazed less than $5 \mathrm{~min} / \mathrm{h}$ until the a.m. milking. Grazing activity in supplemented treatments, on the other hand, was intense $(>45 \mathrm{~min} / \mathrm{h})$ only for $2 \mathrm{~h}$ after the a.m. milking, which was followed by 15 to $35 \mathrm{~min}$ grazing/h until the p.m. milking. After this, the pattern of grazing activity of supplemented cows was similar to that of unsupplemented cows (i.e., $2 \mathrm{~h}$ of intensive grazing were followed by little grazing at night). Grazing activity between 2100 and $0300 \mathrm{~h}$ was slightly lower in supplemented than in unsupplemented treatments.

\section{Pasture Harvested and Milk Production per Hectare}

The proportion of pasture harvested above $2.5 \mathrm{~cm}$ was greater at low than at high PA ( 0.55 vs. $0.33 ; P<$ 0.001 ) and with 0 than with $8 \mathrm{~kg}$ of supplement DM (0.55 vs. $0.33 ; P<0.001$; Table 4$)$. Accordingly, the proportion of pasture harvested above ground level decreased from low to high PA $(0.24$ vs. $0.16 ; P<0.001)$ and from 0 to $8 \mathrm{~kg}$ of supplement DM (0.24 vs. $0.16 ; P$ $<0.001)$. Production of $4 \% \mathrm{FCM}$ per hectare decreased with increasing PA $(-18 \mathrm{~kg} / \mathrm{ha}$ per $\mathrm{kg}$ of PA above ground level; $P<0.001)$ and increased with increasing supplementation $(58 \mathrm{~kg} / \mathrm{ha}$ per $\mathrm{kg}$ of supplement DM; $P<0.001)$. Production of $4 \%$ FCM per hectare, however, tended to increase more with supplementation at low than at high PA (66 vs. $34 \%$; interaction PA $\times$ supplementation; $P=0.06)$.

\section{DISCUSSION}

The aim of the present study was to determine the effect of PA and corn silage supplementation on dairy cows grazing low-mass pastures. This was successfully accomplished, as the pre-grazing pasture mass was only $1.8 \mathrm{t}$ of $\mathrm{DM} /$ ha above $2.5 \mathrm{~cm}$, which is lower than the 3 to $5 \mathrm{t}$ of $\mathrm{DM} /$ ha (above 2 or $3 \mathrm{~cm}$ ) measured with medium- to high-mass pastures (Malossini et al., 1995; 

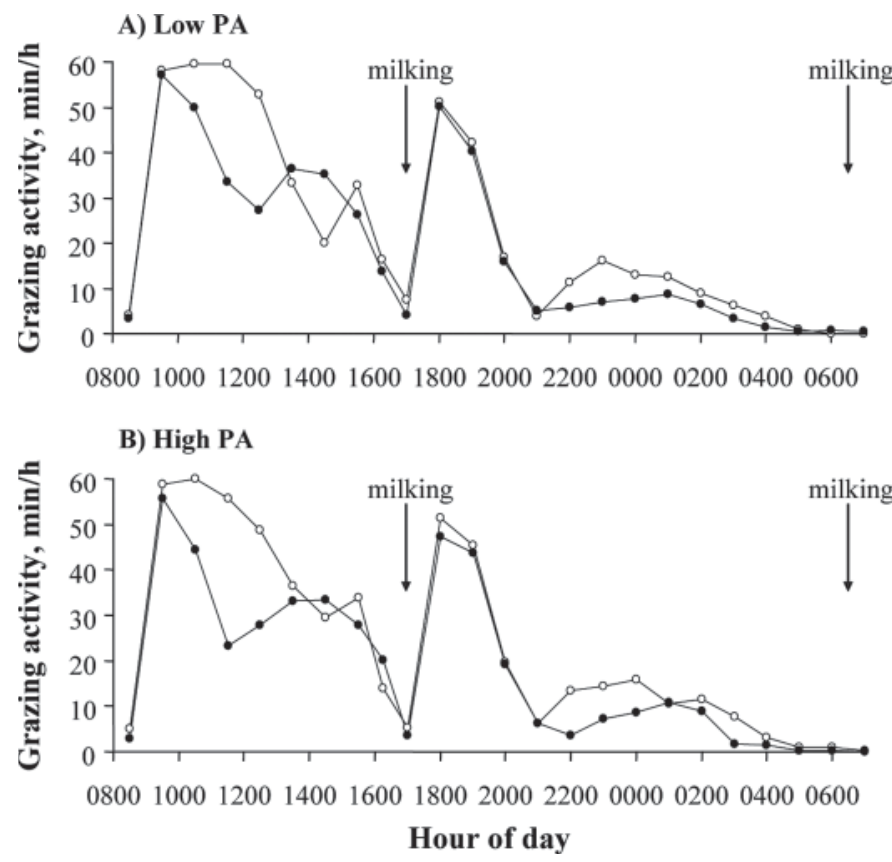

Figure 1. Daily pattern of grazing activity of dairy cows grazing low-mass pasture in autumn according to corn silage/soybean meal supplementation $(\bigcirc=0 \mathrm{~kg}$ of $\mathrm{DM} / \mathrm{d} ; \boldsymbol{\bullet}=8 \mathrm{~kg}$ of DM/d) and pasture allowance (PA). (A) Low PA and (B) high PA.

Stakelum and Dillon, 2004). Furthermore, the pre-grazing plate meter pasture height (i.e., $6.3 \mathrm{~cm}$ ) was quite short, being comparable with the 5 to $7 \mathrm{~cm}$ previously reported in the experiments of Wales et al. (1999), Gibb et al. (1997), and Pérez-Prieto et al. (2011), conducted with low-mass or low-height pastures.

\section{Pasture Characteristics and Defoliation}

Pasture conditions during autumn are quite variable because they are directly related to weather conditions during summer and early autumn. In the present study, the quality of the pasture was penalized due to low rainfall both before and during the trial. The $\mathrm{CP}$ concentration (11.5\% of DM) and OM digestibility (62\%) were much lower than that usually recorded with good quality perennial ryegrass swards during the same season (Dillon et al., 1998; Delagarde et al., 2000; Valk et al., 2000), but corresponded to that reported by Stakelum (1986) and Stockdale (1999) under similar adverse weather conditions. The low quality of the pasture was likely due to the accumulation of dead material since summer. Accordingly, the selected pasture was rich in dead material (0.34) and the sward bulk density above ground level $(620 \mathrm{~kg}$ of $\mathrm{DM} /$ ha per $\mathrm{cm})$ was in the range of 600 to $800 \mathrm{~kg}$ of $\mathrm{DM} /$ ha per cm previously reported by Michell and Large (1983), with swards containing large amounts of senescent material. This, however, was high compared with the 300 to $500 \mathrm{~kg}$ of $\mathrm{DM} /$ ha per $\mathrm{cm}$ usually reported with swards low in dead material (Ribeiro Filho et al., 2005; Pérez-Prieto et al., 2011).

The leaf-to-stem ratio of the pasture was favorable for grazing as pseudostem height represented only 0.20 of extended tiller height. This is typical of leafy swards during autumn (Delagarde et al., 2000) and winter (Pérez-Prieto et al., 2011), whereas pseudostem height is typically 0.30 to 0.40 of tiller height in spring pastures in vegetative stage (Ribeiro Filho et al., 2005; Pérez-Ramírez et al., 2009). Accordingly, at low PA and unsupplemented treatment, cows were able to graze until a very low post-grazing extended tiller height (i.e., $4.9 \mathrm{~cm}$ ), similarly to severe grazing conditions in winter (Pérez-Prieto et al., 2011). This was not reflected in post-grazing pasture height when measured with the plate meter $(4.1 \mathrm{~cm})$, the dead material accumulation probably increasing the stubble's resistance to compression and, hence, impeding short readings. Shorter plate meter post-grazing pasture heights have been recorded under severe grazing conditions (Stockdale, 1999; Kennedy et al., 2009; Pérez-Prieto et al., 2011).

\section{Pasture Intake, Milk Production, and Grazing Behavior of Unsupplemented Cows}

Unsupplemented cows were underfed, theoretical $\mathrm{NE}_{\mathrm{L}}$ requirements being satisfied only in 65 and $76 \%$ at low and high PA, respectively. The primary consequence was that actual 4\% FCM production (11.2 $\mathrm{kg} / \mathrm{d}$ ) was almost $5 \mathrm{~kg}$ lower than the expected $4 \%$ FCM production $(16.1 \mathrm{~kg} / \mathrm{d})$ calculated from the preexperimental value and a monthly persistency of $90 \%$. This underfeeding should be related, at least in part, to the low OM digestibility of the selected pasture (67\%), which restricted pasture ingestibility and nutritive value (Corbett et al., 1963; INRA, 2007). According to the review of Conrad et al. (1964), a decrease in pasture OM digestibility from 80 to $67 \%$ results in $37 \%$ less voluntary energy intake of dairy cows fed ad libitum. Consequently, a high-quality pasture $(80 \%$ of $\mathrm{OM}$ digestibility) with no intake limitation from grazing conditions could have probably satisfied the theoretical $\mathrm{NE}_{\mathrm{L}}$ requirements of the cows. The low pasture quality was, therefore, a primary factor restricting energy supply.

It can, thus, be hypothesized that unsupplemented cows were very hungry, which is supported by their long first grazing bout after pasture allocation in the morning (i.e., $260 \mathrm{~min}$ ). This was even longer than the 200 to 230 min recorded under severe grazing conditions or after a long starvation period (Pérez-Ramírez et al., 2008; Pérez-Ramírez et al., 2009; Pérez-Prieto et al., 2011). Moreover, low pasture mass and height 
clearly limited the PI rate in spite of the severe energy deficit of the cows. The PI rate in unsupplemented treatments was close to the $20 \mathrm{~g}$ of $\mathrm{DM} / \mathrm{min}$ reported for dairy cows continuously grazing short swards of good quality (Rook et al., 1994; Gibb et al., 1997). In these studies, however, cows extended their grazing time to even more than $600 \mathrm{~min} / \mathrm{d}$ to compensate totally or partially for the low PI rate. The $539 \mathrm{~min} / \mathrm{d}$ of grazing time recorded in our trial was, therefore, relatively short and similar to the 450 to $550 \mathrm{~min} / \mathrm{d}$ typically recorded with higher pasture mass and greater PI rate (Stakelum and Dillon, 2004; Kennedy et al., 2009; Pérez-Ramírez et al., 2009). In the current study, long grazing bouts were recorded at night (i.e., 1.5 to $2.0 \mathrm{~h}$ ), clearly indicating that the lack of light was not an absolute limit for grazing and that short daylight in autumn cannot explain per se the relatively short grazing time. The cows' motivation to continue grazing was probably decreased because of the increasing difficulty for grazing the sward and the presence of dead material when grazing lower into the sward profile. Therefore, PI was limited, at least in part, by a cumulative effect of the low-mass and the low quality of the pasture even at high PA, where the amount of pasture on offer was not a limiting factor. This can explain the low effect of PA on PI observed on unsupplemented cows (i.e., 0.06 $\mathrm{kg}$ of PI per $\mathrm{kg}$ increase in PA above ground level). The typical PI response to PA is in the range 0.10 to 0.30 $\mathrm{kg}$ of PI $/ \mathrm{kg}$ of PA above ground level (Peyraud et al., 1996; Stockdale, 1996; Ribeiro Filho et al., 2005).

The average increase in milk production with increasing PA (i.e., $0.06 \mathrm{~kg} / \mathrm{kg}$ of PA above ground level) was among the lowest values reported in the literature (range: 0.0 to $0.4 \mathrm{~kg} / \mathrm{kg}$ of PA above ground level; Peyraud et al., 1996; Wales et al., 1999; Bargo et al., 2002). This is consistent with the small variation in PI with increasing PA, and suggests that the increase in milk production was mainly because of the higher quality of the selected pasture at high than at low PA (OM digestibility $=67.9$ vs. $65.3 \%$ and $\mathrm{NE}_{\mathrm{L}}=5.62$ vs. 5.26 $\mathrm{MJ} / \mathrm{kg}$ of DM).

\section{Substitution Rate and Milk Yield Response to Supplementation}

In the present study, the SR averaged 0.63 , which is in the range of 0.58 to 0.77 reported within the same range of PA by supplementing dairy cows in early to midlactation with 4 to $5 \mathrm{~kg}$ of corn silage DM on good quality pasture (Moran et al., 1986; Graf et al., 2005; Morrison and Patterson, 2007). The SR is known to be affected by several pasture, animal, and supplement factors such as PA, pasture mass (sward height), pasture quality, milk production level, stage of lactation, and amount and type of supplementation (Stockdale, 2000; INRA, 2007). The average observed SR may be regarded as high when considering the negative effect of the low mass and low quality of the pasture on $\mathrm{NE}_{\mathrm{L}}$ supply. Indeed, underfed dairy cows with a negative $\mathrm{NE}_{\mathrm{L}}$ balance strongly decrease $\mathrm{SR}$ compared with wellfed dairy cows (Faverdin et al., 1991; Stockdale, 2000; INRA, 2007). The inclusion of $1 \mathrm{~kg}$ of soybean meal DM in the supplement may also have decreased SR because of the lower SR with concentrates than with forages (Stockdale, 2000; INRA, 2007). Conversely, the average observed SR may be considered as low, regarding the late stage of lactation of the cows (Faverdin et al., 1991) and the high level of corn silage supplementation (Moran and Croke, 1993), both factors being recognized for increasing SR.

The increase in SR from low to high PA recorded in the present study (0.51 vs. 0.75$)$ is consistent with the few grazing experiments examining the effect of PA on SR with forage-supplemented dairy cows (Moate et al., 1984; Stockdale, 1996). In these studies, cows were supplemented with 4 to $6 \mathrm{~kg}$ of corn silage DM and the SR increased from 0.20 to approximately 0.40 from low to high PA. These results suggest that SR between pasture and a forage supplement is regulated by the energy balance of the unsupplemented cows, as it had already been observed for SR between pasture and concentrates (Stockdale, 2000) and between conserved forages and concentrates (Faverdin et al., 1991).

The high supplementation level led to a significant increase in energy and protein supply for supplemented cows, irrespective of PA. Accordingly, the $\mathrm{NE}_{\mathrm{L}}$ supply was higher than the theoretical $\mathrm{NE}_{\mathrm{L}}$ requirements. In fact, more than $55 \%$ of $\mathrm{NE}_{\mathrm{L}}$ requirements were met by the supplement, a relatively small amount of pasture (i.e., $\sim 7.5 \mathrm{~kg}$ of $\mathrm{DM} / \mathrm{d}$ ) being sufficient to satisfy total $\mathrm{NE}_{\mathrm{L}}$ requirements (INRA, 2007). This favorable nutritional status of the supplemented cows probably explains their strong behavioral adaptation compared with unsupplemented cows. It is highly probable that the shorter first grazing bout of supplemented cows was partly related to the time of supplement distribution, which was just before new strip allocation. Nevertheless, the strong decrease in grazing time (436 vs. $539 \mathrm{~min} /$ d; i.e., $-19 \%$ ) and particularly in PI rate (17 vs. $23 \mathrm{~g}$ of $\mathrm{DM} / \mathrm{min}$; i.e., $-35 \%$ ) clearly indicate lower motivation to graze. The decrease in grazing time with supplementation was similar to that previously reported with both forage (Graf et al., 2005) and concentrate supplementation (Bargo et al., 2003). On the other hand, such a high variation on daily PI rate has been only reported under severe restrictions of daily pasture access time ( 4 to $5 \mathrm{~h} / \mathrm{d}$; Pérez-Ramírez et al., 2008; Kennedy et al., 2009; Pérez-Ramírez et al., 2009) 
or by simultaneously decreasing access time (22 vs. 8 h) and corn silage supplementation (5.6 vs. $0 \mathrm{~kg}$ of $\mathrm{DM} / \mathrm{d}$; Graf et al., 2005). The relative PI decrease in supplemented treatments would, therefore, be better explained by the decrease in PI rate $(\sim 60 \%)$ than by the decrease in grazing time $(\sim 40 \%)$. This result contradicts McGilloway and Mayne (1996) and Bargo et al. (2002), who inferred that the major factor explaining SR is the decrease in grazing time.

Previous research reported that milk yield response to forage supplementation is decreased with increasing PA because of an increasing SR (Moate et al., 1984; Stockdale, 1996). In the current study, the milk yield response was expected, therefore, to be lower at high PA because of the higher PI and higher SR. The response in milk production (i.e., $0.67 \mathrm{~kg} / \mathrm{kg}$ of supplement DM), however, did not vary according to PA and was high considering that the average PA was high ( $50 \mathrm{~kg}$ of DM/d above ground level) and that the values reported for cows grazing at high PA do not exceed 0.4 $\mathrm{kg}$ of milk $/ \mathrm{kg}$ of corn silage DM (Moran et al., 1986; Graf et al., 2005; Morrison and Patterson, 2007). In fact, the greatest responses in milk production from feeding supplementation of grazing dairy cows occur when cows are underfed on pasture alone (Stockdale, 2000; Burke et al., 2008). This was clearly demonstrated by Stockdale (1996) where milk yield response to corn silage supplementation increased from 0.1 to $0.8 \mathrm{~kg} / \mathrm{kg}$ of supplement DM when PA was decreased from 39 to $19 \mathrm{~kg}$ of DM/d at ground level. In our trial, the unsupplemented cows were underfed at both PA because of the low $\mathrm{NE}_{\mathrm{L}}$ supply from the pasture, a high milk yield response being recorded even at high PA.

\section{Practical Implications for Grazing Low-Mass Pastures in Autumn}

Milk production per cow increased by increasing PA and supplementation. The profitability of pasturebased dairy systems, however, depends primarily on the efficiency of pasture use per hectare if reasonable performance per cow is achieved (Dillon et al., 2005). In this experiment, the inclusion of corn silage/soybean meal supplementation improved the $\mathrm{NE}_{\mathrm{L}}$ balance and the $4 \%$ FCM production per hectare, but decreased the proportion of pasture harvested above ground level by approximately $35 \%$ at both PA. With or without supplementation, the decrease from high to low PA resulted in a moderate decrease in individual $4 \% \mathrm{FCM}$ production $(-5$ to $-15 \%)$, but in a great increase in $4 \%$ FCM production per hectare $(+35$ to $+65 \%)$. This was similar in trend to that previously reported in both short-term studies (Ribeiro Filho et al., 2005; PérezPrieto et al., 2011) and long-term studies (Macdonald et al. 2008; O'Donovan and Delaby, 2008). A low PA may, thus, be used even with low-mass pastures in autumn to improve pasture use efficiency, considering the relatively small decrease in per cow performance.

In the present study, the proportion of pasture harvested at ground level did not exceed 0.30 , even at low PA (i.e., high grazing pressure), which was smaller than the 0.35 to 0.45 proportion reported for cows severely grazing low-mass pastures (Wales et al., 1999; PérezPrieto et al., 2011). Moreover, it was almost half that measured with higher pasture mass (0.55 to 0.65; Peyraud et al., 1996; Ribeiro Filho et al., 2005). This was likely related to the high proportion of dead material, which was scarcely consumed by the cows, but also to the fact that a high proportion of the pasture was close to the ground and not easily harvestable (54\% DM below $2.5 \mathrm{~cm}$ ). These results highlighted the fact that guidelines in terms of proportion of pasture harvested should be adapted to low-mass pastures to avoid a decrease in per-cow performance. A post-grazing plate meter pasture height of approximately $4.5 \mathrm{~cm}$ and $8 \mathrm{~kg}$ of corn silage/soybean supplement DM/d seems to be a good practice guideline when late-lactation dairy cows are grazing low-mass pastures of low quality. Cows are able to satisfy their nutritional requirements and milk production per hectare is increased.

\section{CONCLUSIONS}

The present results clearly indicate that unsupplemented late-lactation dairy cows are unable to fully satisfy their nutritional requirements when grazing lowmass pastures of low quality during autumn. Pasture allowance had little effect on PI because the low-mass pasture (low pasture height) resulted in a low intake rate, and the low quality of the pasture, added to the difficulty of grazing the short swards, limited the grazing time. Energy intake was, therefore, very low in unsupplemented cows, and greatly increased with corn silage/soybean supplementation. This was due to a SR lower than 1 and a higher nutritive value of the supplement than that of the pasture. Under these conditions, the milk yield response to corn silage/soybean supplementation was high.

\section{ACKNOWLEDGMENTS}

The financial support of both the Comisión Nacional de Investigación Científica y Tecnológica (CONICYT, Chile) and the French Embassy in Chile in the form of the first author's $\mathrm{PhD}$ scholarship are gratefully acknowledged. This research was partly funded by the Programme Sur et Pour le Développement Régional Grand Ouest (PSDR GO), Project Laitop. The au- 
thors sincerely thank J. Lassalas and P. Lamberton (UMR1080 Production du Lait, Méjusseaume farm, Le Rheu, France) for their technical assistance. Many thanks to J. M. Aubry, D. Chevrel, A. Cozien, B. Gréhal, J. L. Harel, M. Lemarchand, M. Texier, and G. Théaud from the Méjusseaume farm (UMR1080 Production du Lait, Le Rheu, , France) for their care of the experimental animals, grazing management, data processing, and assistance with measurements throughout the study. Gratitude is also expressed to L. Finot, N. Huchet, and T. Le Mouel (UMR1080 Production du Lait, Saint-Gilles, France), who performed laboratory chemical analyses. Caractères et caetera (Rennes, France) post-edited the manuscript.

\section{REFERENCES}

Association Française de Normalisation. 1997. Aliments des animauxDosage de l'azote - Méthode par combustion (DUMAS) - NF V18120; Dosage des cendres brutes-NF V18-101. AFNOR Editions, Saint-Denis La Plaine, France.

Aufrère, J., and B. Michalet-Doreau. 1988. Comparison of methods for predicting digestibility of feeds. Anim. Feed Sci. Technol. 20:203-218.

Bargo, F., L. D. Muller, J. E. Delahoy, and T. W. Cassidy. 2002. Milk response to concentrate supplementation of high producing dairy cows grazing at two pasture allowances. J. Dairy Sci. 85:17771792 .

Bargo, F., L. D. Muller, E. S. Kolver, and J. E. Delahoy. 2003. Invited review: Production and digestion of supplemented dairy cows on pasture. J. Dairy Sci. 86:1-42.

Brun, J. P., S. Prache, and G. Béchet. 1984. A portable device for eating behaviour studies. In Proc. 5th Mtg. Eur. Graz. Workshop, Hill Farming Research Organisation, Midlothian, UK.

Burke, F., M. A. O'Donovan, J. J. Murphy, F. P. O'Mara, and F. J. Mulligan. 2008. Effect of pasture allowance and supplementation with maize silage and concentrates differing in crude protein concentration on milk production and nitrogen excretion by dairy cows. Livest. Sci. 114:325-335.

Conrad, H. R., A. D. Pratt, and J. W. Hibbs. 1964. Regulation of feed intake in dairy cows. I. Change in importance of physical and physiological factors with increasing digestibility. J. Dairy Sci. 47:54-62.

Corbett, J. L., J. P. Langlands, and G. W. Reid. 1963. Effects of season of growth and digestibility of herbage on intake by grazing dairy cows. Anim. Prod. 5:119-129.

Delagarde, R., J. L. Peyraud, and L. Delaby. 2000. Influence of herbage allowance on intake and behaviour of dairy cows grazing perennial ryegrass swards in autumn. Pages 101-102 in Occasional Symposium No. 34 Br. Grassl. Soc., Harrogate, UK. Grazing management. A. J. Rook and P. D. Penning, ed. British Grassland Society, Reading, UK.

Dillon, P., S. Crosse, and J. R. Roche. 1998. The effect of grazing intensity in late summer/autumn on sward characteristics and milk production of spring-calving dairy cows. Ir. J. Agric. Food Res. $37: 1-15$.

Dillon, P., J. R. Roche, L. Shalloo, and B. Horan. 2005. Optimising financial return from grazing in temperate pastures. Pages 131-147 in Proc. Satellite Workshop 20th Int. Grassl. Congr., Cork, Ireland. Utilisation Grazed Grass in Temp. Anim. Syst. J. J. Murphy, ed. Wageningen Academic Publishers, Wageningen, the Netherlands.

Faverdin, P., J. P. Dulphy, J. B. Coulon, R. Vérité, J. P. Garel, J. Rouel, and B. Marquis. 1991. Substitution of roughage by concentrates for dairy cows. Livest. Prod. Sci. 27:137-156.
Gibb, M. J., C. A. Huckle, R. Nuthall, and A. J. Rook. 1997. Effect of sward surface height on intake and grazing behaviour by lactating Holstein Friesian cows. Grass Forage Sci. 52:309-321.

Graf, C. M., M. Kreuzer, and F. Dohme. 2005. Effects of supplemental hay and corn silage versus full-time grazing on ruminal $\mathrm{pH}$ and chewing activity of dairy cows. J. Dairy Sci. 88:711-725.

INRA (French National Institute for Agricultural Research). 2007. Alimentation des bovins, ovins et caprins: Besoins des animaux - Valeurs des aliments. Editions QUAE, Versailles, France.

Jones, B., and M. G. Kenward. 1989. Design and analyses for three or more treatments. Pages 189-241 in Design and Analysis of CrossOver Trials. Monographs on Statistics and Applied Probability No. 34. D. R. Cox, D. V. Hinkley, D. Rubin, and B. W. Silverman, ed. Chapman and Hall, London, UK.

Kennedy, E., M. McEvoy, J. P. Murphy, and M. O'Donovan. 2009. Effect of restricted access time to pasture on dairy cow milk production, grazing behavior, and dry matter intake. J. Dairy Sci. 92:168-176.

Macdonald, K. A., J. W. Penno, J. A. S. Lancaster, and J. R. Roche. 2008. Effect of stocking rate on pasture production, milk production, and reproduction of dairy cows in pasture-based systems. J. Dairy Sci. 91:2151-2163.

Malossini, F., S. Bovolenta, C. Piras, and W. Ventura. 1995. Effect of concentrate supplementation on herbage intake and milk yield of dairy cows grazing an alpine pasture. Livest. Prod. Sci. 43:119 128

Mayes, R. W., C. S. Lamb, and P. M. Colgrove. 1986. The use of dosed and herbage n-alkanes as markers for the determination of herbage intake. J. Agric. Sci. (Camb.) 107:161-170.

McGilloway, D. A., and C. S. Mayne. 1996. The importance of grass availability for the high genetic merit dairy cow. Pages 135-169 in Recent Advances in Animal Nutrition. P. C. Garnsworthy, J. Wiseman, and W. Haresign, ed. Nottingham University Press, Nottingham, UK.

Michell, P., and R. V. Large. 1983. The estimation of herbage mass of perennial ryegrass swards: A comparative evaluation of a risingplate meter and a single-probe capacitance meter calibrated at and above ground level. Grass Forage Sci. 38:295-299.

Moate, P. J., G. L. Rogers, and I. B. Robinson. 1984. Effect of level of silage supplement and pasture allowance on pasture intake, milk yield and milk composition of grazing cows. Proc. Aust. Soc. Anim. Prod. 15:722.

Moran, J. B., and D. E. Croke. 1993. Maize silage for the pasture-fed dairy cow. 5. A comparison with wheat while grazing low quality perennial pastures in the summer. Aust. J. Exp. Agric. 33:541549.

Moran, J. B., C. R. Stockdale, and T. E. Trigg. 1986. Maize silage as a supplement for grazing dairy cows. Proc. Aust. Soc. Anim. Prod. 16:283-286.

Morrison, S. J., and D. C. Patterson. 2007. The effects of offering a range of forage and concentrate supplements on milk production and dry matter intake of grazing dairy cows. Grass Forage Sci. 62:332-345.

O'Donovan, M., and L. Delaby. 2008. Sward characteristics, grass dry matter intake and milk production performance is affected by timing of spring grazing and subsequent stocking rate. Livest. Sci. 115:158-168.

Pérez-Prieto, L. A., J. L. Peyraud, and R. Delagarde. 2011. Pasture intake, milk production and grazing behaviour of dairy cows grazing low-mass pastures at three daily allowances in winter. Livest. Sci. 137:151-160. doi:10.1016/j.livsci.2010.10.013.

Pérez-Ramírez, E., R. Delagarde, and L. Delaby. 2008. Herbage intake and behavioural adaptation of grazing dairy cows by restricting time at pasture under two feeding regimes. Animal 2:1384-1392.

Pérez-Ramírez, E., J. L. Peyraud, and R. Delagarde. 2009. Restricting daily time at pasture at low and high pasture allowance: Effects on pasture intake and behavioral adaptation of lactating dairy cows. J. Dairy Sci. 92:3331-3340.

Peyraud, J. L., E. A. Comerón, M. H. Wade, and G. Lemaire. 1996. The effect of daily herbage allowance, herbage mass and animal 
factors upon herbage intake by grazing dairy cows. Ann. Zootech. 45:201-217.

Ribeiro Filho, H. M. N., R. Delagarde, and J. L. Peyraud. 2005. Herbage intake and milk yield of dairy cows grazing perennial ryegrass swards or white clover/perennial ryegrass swards at low- and medium-herbage allowances. Anim. Feed Sci. Technol. 119:13-27.

Rook, A. J., C. A. Huckle, and R. J. Wilkins. 1994. The effects of sward height and concentrate supplementation on the performance of spring calving dairy cows grazing perennial ryegrass-white clover swards. Anim. Prod. 58:167-172.

SAS Institute. 1999. SAS User's Guide: Statistics. SAS Institute Inc., Cary, NC.

Stakelum, G. 1986. Herbage intake of grazing dairy cows. 3. Effects of herbage mass, herbage allowance and concentrate feeding on the herbage intake of dairy cows grazing on mid-summer pasture. Isr. J. Agric. Res. 25:179-189.

Stakelum, G., and P. Dillon. 2004. The effect of herbage mass and allowance on herbage intake, diet composition and ingestive behaviour of dairy cows. Ir. J. Agric. Food Res. 43:17-30.

Stockdale, C. R. 1996. Substitution and production responses when lactating dairy cows graze a white clover pasture supplemented with maize silage. Aust. J. Exp. Agric. 36:771-776.

Stockdale, C. R. 1997. Supplements improve the production of dairy cows grazing either white clover or paspalum-dominant pastures in late lactation. Aust. J. Exp. Agric. 37:295-302.

Stockdale, C. R. 1999. Effects of cereal grain, lupins-cereal grain or hay supplements on the intake and performance of grazing dairy cows. Aust. J. Exp. Agric. 39:811-817.
Stockdale, C. R. 2000. Levels of pasture substitution when concentrates are fed to grazing dairy cows in northern Victoria. Aust. J. Exp. Agric. 40:913-921.

Stockdale, C. R., and D. W. Dellow. 1995. The productivity of lactating dairy cows grazing white clover and supplemented with maize silage. Aust. J. Agric. Res. 46:1205-1217.

Valk, H., I. E. Leusink-Kappers, and A. M. van Vuuren. 2000. Effect of reducing nitrogen fertilizer on grassland on grass intake, digestibility and milk production of dairy cows. Livest. Prod. Sci. 63:27-38.

Van Soest, P. J., J. B. Robertson, and B. A. Lewis. 1991. Methods for dietary fiber, neutral detergent fiber, and nonstarch polysaccharides in relation to animal nutrition. J. Dairy Sci. 74:3583-3597.

Vulich, S. A., E. G. O'Riordan, and J. P. Hanrahan. 1991. Effect of litter size on herbage intake at pasture by ewes and their progeny. Anim. Prod. 53:191-197.

Wales, W. J., P. T. Doyle, C. R. Stockdale, and D. W. Dellow. 1999. Effects of variations in herbage mass, allowance, and level of supplement on nutrient intake and milk production of dairy cows in spring and summer. Aust. J. Exp. Agric. 39:119-130.

Woodward, S. L., A. V. Chaves, G. C. Waghorn, and P. G. Laboyrie. 2002. Supplementing pasture-fed dairy cows with pasture silage, maize silage, Lotus silage or sulla silage in summer-Does it increase production? Proc. N. Z. Grassl. Assoc. 64:85-89. 